\title{
Indian Multinational Corporations and Technology Transfer: Prospects and Determinants
}

\author{
Dr. P Abdul Kareem \\ Associate Professor\& Head \\ Department of Economics \\ Central University of Kerala \\ Kasaragod, Kerala, INDIA - 671320
}

\begin{abstract}
In the ongoing process of opening up of the Indian economy, opening up of foreign direct investment sector is important. India witnessed huge inward and outward flows of foreign direct investment after early 1990's. The multinational corporations carry foreign direct investment. The foreign multinational corporations contributed to the development of Indian domestic industrial economy in a significant way. Here, over the period of time the multinational corporations of Indian orgin also emerged. In this context, this study analyses the extent and determinants of technology transfer by Indian multinational corporations. The two multinational corporations such as Reliance Industries and Tata Motors are selected for detailed analysis. Firstly the study analyses the changing structure of embodied technology in terms of intangible assets of these corporations over the period 2003-2017.The intangible assets in terms of product development cost has emerged both in Reliance Industries and Tata Motors. The assets in computer software also significantly increased in both these corporations.
\end{abstract}

The various determinants of technology transfer are outward foreign direct investment, trade openness and Research \& Development expenditure by Government. The Johansen and Juselius Co-integration Test and Fully Modified Least Square (FMOLS) methods are applied to estimate the determinants. The study reveals that the Government expenditure on $R \& D$ very significantly result in the technology transfer by both multinationals. Next, the degree of trade openness significantly lead to technology transfer by both the multinationals. Then, the quantity of outward foreign direct investment also leads to technology transfer. This is so with both Reliance industries and Tata Motors. From this analysis we may draw the inference that higher openness in terms of trade openness and higher outward foreign direct investment followed by large Government expenditure on research and development provide huge prospects for Indian multinational corporations in the global economy.

Keywords: Economic Reforms, Indian Multinationals, Technology Transfer

\section{Section I- Introduction}

The opening up of the trade sector and foreign direct investment sector are the important features of the economic reforms implimented in India after 1991. Subsequently the trade and foreign direct investment sectors have emerged in a huge way and this has resulted in higher economic performance in the country. Due to transnationalisation of production, capital and technology, Indian economy was transformed into a fast growing economy in the world. The inward and outward flow of foreign direct investment after 1991made remarkable developments in the Indian economy. This foreign direct investment has resulted in growth of capital, employment,technology etc. In due course of the reform period many large multinational corporations from Indian origin made huge investments abroad. In this context, this paper estimates the extent and determinants of technology transfer by Indian multinationals. For the purpose of detailed study we have selected large multinationals such as Tata Motors and Reliance Industries. In the first section,we give introduction. In the second section we have reviewed the available literature. The prospects of technology transfer by Indian Multinational are discussed in section III and the determinants of technology transfer are estimated in section IV. The final section $\mathrm{V}$ provide conclusion.

\section{Section II- Review of Literature}

Ayres (1953) explains the role of technology in economic theory. The paper starts with the cognitive nature of human behaviour. Here technology is perceived to be doing- a mode of doing, perhaps, but one that runs through the whole gamut of human activities. According to Ayres, technology is workmanship and it includes the workmanship of scientists and artists no less than the commoner skills we all acquire. All new devices are combinations of old ones, and so are all the discoveries of the scientists and all the creations of the artists. The machine process is the key to our productive powers. But what makes them productively potent is their technical efficiency. 
Today industrial growth is a consequence of technological development and it is generally recognised that research is the key to further industrial development.

According to Metcalfe (2009), technology and technological change play a central role in economics, whether in the theory of resource allocation or in the theory of growth and development. Yet the nature of technology is largely ignored in economic theory, it being considered sufficient to treat technology as a constraint on productive opportunities. Metcalfe delves a little deeper into the nature of technology and the material,energy and information transformation processes that it represents. A deeper understanding of technology leads to a deeper understanding of the main currents of technological advance and to the reasons why the development of technology and its applications are so uneven over time and place.

The main objective of the study by Wahab et al (2012) is to contribute to the existing technology transfer literature by reviewing and out lining the mechanism (channels) of technology transfer. This review aims to stimulate and generate dynamic ideas for future researchers, ie to further identify and understand the technology transfer's channels, the parties involved, the type of technologies in the transfer process and the justification for selecting specific mode of transfer. Since technology transfer literatures cover a wide research area, this study sets its parameter by focusing on the transfer mechanisms which involve both intra and inter-firm technology transfer.

The study by Aggarwal and Weekly(1982) endeavoured to identify and examine the features of those Third world multinational enterprises that have been included in earlier studies and to determine the extent to which multinational firms based in India conform to the norms of that group. The multinational companies from India share most of the characteristics of MNCs based in other Third world countries. Motives for foreign direct investment that Indian companies share with other TWMNCs include restricted opportunities for domestic growth because of antitrust and market size reasons, the need to protect export markets and encouragement from the home country government.

Most foreign operations of Indian firms, like their counterparts in other TWMNCs emphasize low cost, labourintensive, small-scale operations using mostly intermediate-level technology to serve markets. The study by Yang et al(2018) examines the determinants of intangible investment by private manufacturing firms and its impacts on firms' productivity in China. Higher human capital, larger firm size and better institutional quality are found to increase the propensity and the amount of intangible investment. The study provides evidence that the disaggregated components of intangibles are positively correlated with firm productivity and there is complementarity between software and organisation investment. The examples of intangible capital include research and development investment, organisation capital, technology licenses, patents and copy right.

Oliveira and Mayer (2017) explain that foreign direct investment is one channel of technology transfer through Joint Ventures (JV), Wolly Owned by Subsidiaries (WoS) and Merger and Acquisitions (M \& A). The other channels are trade in goods and services, knowledge exchange and movement of human capital.

According to Radosevic(2019), the analysis of technology transfer should be ecletic in order to cope with the multidimensionality of technology. Effective technology transfer is not a matter of identifying one or two best channels but it is the result of a combination of appropriate modes which are highly dependent on industry, technology and the level of a country's development. To Fazal and Wahab (2014) MNCs transfer technology in tangible forms and intangible forms. They explain that studies are required to understand technology transfer in different countries. Tiwari and Herstatt (2009) find that Germany has advanced to the position of a key destination for Indian multinational enterprises. In 2008, Indian firms invested an estimated amount of US \$1.8 billion in Germany while 16 acquisitions by Indian firms were monitored, up from 7 in 2007. In fact, Indian FDI stock in Germany seems to have surpassed German FDI stock in India. The study shows that, as of October 2008, 123 Indian MNCs with 167 subsidiaries were active in Germany. Kumar (1995) explains that inter-developing country foreign direct investments and technology transfers should continue to be encouraged as a part of economic and technological co-operation among developing countries. Further, Iyer(2009) suggests that multinationals exhibit greater productivity than local firms. The results of this study suggest that Indian multinationals have higher productivity than foreign multinationals.

\section{Section III- Prospects of Technology Transfer by Indian Multinational Corporations}

In order to study the prospects of technology transfer by Indian multinationals we have selected two leading industrial corporates in the country such as Tata Motors and Reliance Industries, The data are collected from the Annual Reports of these Industries. The intangible assets variable can be taken to represent the embodied technology of an industry (Yang etal 2018). This intangible assets will give an idea of the extent of technology transfer by these Indian multinational corporations abroad. Here, we firstly analyse the structure of intangible assets of Tata Motors during the period 2003-2017 in Table 1. The various components of intangible assets are technical know how, computer software, product development cost, trade marks and brand and developed technologies. The assets in product development cost has emerged to be major assets over the period of time. 
In 2003, the product development cot was Rs.5,966.68 crores and it increased to Rs. 5,0681.24 crores in the year 2016. In 2017, the total product development cost was Rs.4,7746.09crores. Next, the investment in computer software has increased over the same period. In 2005, Tata Motors has invested Rs.59.90 crores in computer software and it increased to Rs.5,96.68crores in 2016. In 2017 ,the software assets were of the tune Rs.5,212.84 crores. The next intangible asset is in trade marks and brand. In 2017, this asset was Rs.5003.50 crores. The assets in technical know how and developed technologies were also significant. The total intangible assets of Tata Motors consistently increased from Rs.51.64 crores in 2003 to Rs.59, 967.71crores in 2017. This huge intangible assets shows the emerging prospects of technology transfer by the Tata Motors industry abroad. This increasing prospect was evident particularly after 2011.

Table 2 shows the structure of intangible assets of Reliance Industries during the period 2003-2017. Here also we can find that the component of assets in Development Rights occupy huge share with Rs.80, 271.0crores in 2015. In the year 2017 the total assets in development right was Rs.41, 304.0crores. The next component is the assets in technical know how. In 2003, the assets in technical know howwas Rs.1, 741.88 was crores and it consistently increased over the years. In 2017, this asset was Rs.3601.0 crores. The investment in software also increased over the period. This was Rs.85.84 crores in 2003 and it increased to Rs.1,499.0crores in 2015. The total intangible assets of Reliance Industries was Rs.1, 827.72crores in 2003 and this increased to Rs.89,313.0 crores in 2015. In 2017, this total asset remained at Rs.54,123. This increasing trend of intangible assets was evident particularly after 2011. This shows the emerging prospects of technology transfer by Reliance Industries abroad.

Table 1. Structure of Intangible Assets of Tata Motors (in Rs. Crores)

\begin{tabular}{|c|l|c|c|c|c|c|c|c|}
\hline $\begin{array}{c}\text { SL } \\
\text { No }\end{array}$ & & $\mathbf{2 0 0 3}$ & $\mathbf{2 0 0 4}$ & $\mathbf{2 0 0 5}$ & $\mathbf{2 0 0 6}$ & $\mathbf{2 0 0 7}$ & $\mathbf{2 0 0 8}$ & $\mathbf{2 0 0 9}$ \\
\hline 01 & Technical Know How & - & 39.04 & 41.85 & - & - & 29.59 & 45.34 \\
\hline 02 & Computer Software & - & - & 59.90 & $\begin{array}{c}112.9 \\
9\end{array}$ & $\begin{array}{c}112.9 \\
9\end{array}$ & $\begin{array}{c}252.0 \\
5\end{array}$ & 977.01 \\
\hline 03 & Product development Cost & 51.64 & 32.21 & 76.18 & $\begin{array}{c}125.9 \\
1\end{array}$ & $\begin{array}{c}156.4 \\
7\end{array}$ & $\begin{array}{c}3 \\
3\end{array}$ & 1552.1 \\
\hline 04 & Trademarks and brand & - & - & - & - & - & - & 2889.47 \\
\hline 05 & Developed Technologies & - & - & - & - & - & - & 940.13 \\
\hline & & $\mathbf{5 1 . 6 4}$ & $\mathbf{7 1 . 2 5}$ & $\mathbf{1 7 7 . 9 3}$ & $\mathbf{2 3 8 . 9}$ & $\mathbf{2 6 9 . 4}$ & $\mathbf{6 5 9 . 7}$ & $\mathbf{6 4 0 4 . 7 0}$ \\
\hline
\end{tabular}

\begin{tabular}{|c|c|c|c|c|c|c|c|c|c|}
\hline SL No & & $\begin{array}{l}201 \\
0\end{array}$ & 2011 & 2012 & $\begin{array}{l}201 \\
3\end{array}$ & 2014 & 2015 & 2016 & 17 \\
\hline 01 & $\begin{array}{l}\text { Technical } \\
\text { Know How }\end{array}$ & $\begin{array}{l}43.6 \\
5\end{array}$ & $\begin{array}{l}37.2 \\
9\end{array}$ & 37.42 & $\begin{array}{c}56 . \\
37\end{array}$ & $\begin{array}{l}56.6 \\
5\end{array}$ & $\begin{array}{l}83.5 \\
0\end{array}$ & $\begin{array}{l}1525.5 \\
6\end{array}$ & $\begin{array}{r}13 \\
13.68\end{array}$ \\
\hline 02 & $\begin{array}{l}\text { Computer } \\
\text { Software }\end{array}$ & $\begin{array}{c}136 \\
7.91\end{array}$ & $\begin{array}{l}1686 \\
.07\end{array}$ & $\begin{array}{l}2255 . \\
27\end{array}$ & $\begin{array}{l}198 \\
4.35\end{array}$ & $\begin{array}{l}3118 \\
.71\end{array}$ & $\begin{array}{l}4572 \\
.82\end{array}$ & $\begin{array}{l}5966.6 \\
8\end{array}$ & $\begin{array}{r}52 \\
12.84\end{array}$ \\
\hline 03 & $\begin{array}{c}\text { Product } \\
\text { development Cost }\end{array}$ & $\begin{array}{l}663 \\
3.18\end{array}$ & $\begin{array}{l}6828 \\
.41\end{array}$ & $\begin{array}{l}1253 \\
8.61\end{array}$ & $\begin{array}{r}210 \\
18.31\end{array}$ & $\begin{array}{l}2922 \\
9.51\end{array}$ & $\begin{array}{l}4045 \\
6.62\end{array}$ & $\begin{array}{l}50681 . \\
24\end{array}$ & $\begin{array}{r}47 \\
746.69\end{array}$ \\
\hline 04 & $\begin{array}{l}\text { Trademarks } \\
\text { and brand }\end{array}$ & $\begin{array}{r}270 \\
6.53 \\
\end{array}$ & $\begin{array}{l}2841 \\
.73 \\
\end{array}$ & $\begin{array}{l}3241 . \\
66\end{array}$ & $\begin{array}{l}326 \\
4.48 \\
\end{array}$ & $\begin{array}{l}3958 \\
.94 \\
\end{array}$ & $\begin{array}{l}3677 \\
.51 \\
\end{array}$ & $\begin{array}{l}5902.1 \\
7\end{array}$ & $\begin{array}{r}50 \\
03.50 \\
\end{array}$ \\
\hline 05 & $\begin{array}{c}\text { Developed } \\
\text { Technologies }\end{array}$ & $\begin{array}{l}852 . \\
94\end{array}$ & $\begin{array}{l}898 . \\
79\end{array}$ & $\begin{array}{l}1021 . \\
65\end{array}$ & $\begin{array}{l}100 \\
4.94\end{array}$ & $\begin{array}{l}1188 \\
.40\end{array}$ & $\begin{array}{l}1122 \\
.39\end{array}$ & 687.08 & $\begin{array}{r}71 \\
1.60\end{array}$ \\
\hline & & $\begin{array}{l}116 \\
04.21 \\
\end{array}$ & $\begin{array}{l}1229 \\
2.29 \\
\end{array}$ & $\begin{array}{c}1909 \\
4.61 \\
\end{array}$ & $\begin{array}{r}273 \\
28.45 \\
\end{array}$ & $\begin{array}{l}3755 \\
2.21 \\
\end{array}$ & $\begin{array}{l}4991 \\
2.84 \\
\end{array}$ & $\begin{array}{l}64762 . \\
73\end{array}$ & $\begin{array}{r}59 \\
98771 \\
\end{array}$ \\
\hline
\end{tabular}

Source: Compiled from various Annual Reports, Tata Motors 
Table 2. Structure of Intangible Assets of Reliance Industries (in Rs. Crores)

\begin{tabular}{|c|c|c|c|c|c|c|c|}
\hline $\begin{array}{r}S \\
\text { L No }\end{array}$ & & 2012 & 2013 & 2014 & 2015 & 2016 & 2017 \\
\hline $\begin{array}{l}0 \\
1\end{array}$ & Technical Know How & 3469.0 & 3492.0 & 3525.0 & 3575.0 & $\begin{array}{l}3595 . \\
0\end{array}$ & $\begin{array}{l}3601 \\
0\end{array}$ \\
\hline $2^{0}$ & Software & 621.0 & 669.0 & 1233.0 & 1499.0 & $\begin{array}{l}977.0 \\
3\end{array}$ & $\begin{array}{l}1003 \\
0\end{array}$ \\
\hline $3^{0}$ & Development Rights & $\begin{array}{c}50847 . \\
0\end{array}$ & $\begin{array}{c}54003 . \\
0\end{array}$ & $\begin{array}{c}67143 . \\
0\end{array}$ & 80271.0 & $\begin{array}{l}3784 \\
9.0\end{array}$ & $\begin{array}{l}4130 \\
4.0\end{array}$ \\
\hline $4^{0}$ & Others & 3776.0 & 3757.0 & 3751.0 & 3968.0 & $\begin{array}{l}9179 . \\
0\end{array}$ & $\begin{array}{l}8215 \\
0\end{array}$ \\
\hline & & $\begin{array}{l}58713 . \\
0\end{array}$ & $\begin{array}{l}61921 . \\
0\end{array}$ & $\begin{array}{c}75652 . \\
0\end{array}$ & 89313.0 & $\begin{array}{l}5160 \\
0.0\end{array}$ & $\begin{array}{c}5412 \\
3.0 \\
\end{array}$ \\
\hline
\end{tabular}

Source: Compiled from various Annual Reports, Reliance Industries Ltd.

\begin{tabular}{|c|c|c|c|c|c|c|c|c|c|}
\hline SL No & & 2003 & 2004 & 2005 & 2006 & 2007 & 2008 & 2009 & 2010 \\
\hline 01 & $\begin{array}{l}\text { Technical } \\
\text { Know How }\end{array}$ & $\begin{array}{l}1741.8 \\
8\end{array}$ & $\begin{array}{l}1740.8 \\
8 \\
\end{array}$ & $\begin{array}{l}1750.1 \\
1\end{array}$ & $\begin{array}{l}1926 . \\
97\end{array}$ & 2102.4 & 2192.9 & $\begin{array}{l}2595.4 \\
0 \\
\end{array}$ & $\begin{array}{l}3079.9 \\
5\end{array}$ \\
\hline 02 & Software & 85.84 & 94.00 & 217.86 & $\begin{array}{l}283.1 \\
8\end{array}$ & 123.6 & 392.3 & 460.87 & 480.69 \\
\hline 03 & $\begin{array}{l}\text { Development } \\
\text { Rights }\end{array}$ & - & - & - & - & - & - & - & - \\
\hline 04 & Others & - & - & - & - & 206.6 & 137.7 & $\begin{array}{l}3568.9 \\
4\end{array}$ & $\begin{array}{l}3568.9 \\
4\end{array}$ \\
\hline & & $\begin{array}{l}1827.7 \\
2\end{array}$ & $\begin{array}{l}1835.8 \\
8\end{array}$ & $\begin{array}{l}1967.9 \\
7\end{array}$ & $\begin{array}{l}2398 . \\
90\end{array}$ & $\begin{array}{l}2632.5 \\
7\end{array}$ & 2722.9 & $\begin{array}{c}6625.2 \\
1\end{array}$ & $\begin{array}{l}7129.5 \\
8\end{array}$ \\
\hline
\end{tabular}

Section IV- Determinants of Technology Transfer by Multinational Corporations

The various determinants of technology transfer by Indian multinationals are outward foreign direct investment in India, trade openness in India and research and development expenditure by the government. There is a positive relationship between these various determinants and the technology transfer. Higher the research and development expenditure by the government, higher will be the technology transfer. Similarly high outward foreign direct investment leads to higher technology transfer by Indian multinationals. Also, higher trade openness defined in terms of exports +imports/GDP ratio also result in technology transfer. In the table 3, we give the unit root test for stationarity problem. The stationary variables are significant at $1 \%$ level and 5\% level of significance.So, there is no spurious behaviour of variables. Next, in Table 4 we have estimated the Johansen and Juseliusco-integration test in the case of Tata Motors. Here both Trace statistics and Max-Eigen statistics are significant at $0.05 \%$ critical value. In table 5, we have estimated the co-integration in the case of Reliance Industries. The Trace statistics and Max-Eigen statistics are significant at $0.05 \%$ critical value. Subsequently, we have applied fully modified least squares (FMOLS) to estimate the various determinants. In table 6 , we give the econometrics result in the case of Tata Motors. The government expenditure on research and development emerge as the important variable leading to technology transfer as evidenced by the magnitude of the coefficient. This is statistically significant also. The variable trade openness also positively resultin higher technology transfer asgiven by the magnitude of coefficient and level of significance. Next, the quantity of outward foreign direct investment also positively result in technology transfer by Indian multinational Tata Motors. In the case of Reliance Industries also, we get the same result of determinants (See Table 7). The government expenditure on research and development emerges as the most important determining factor. Trade openness also significantly result in technology transfer and the outward foreign direct investment leads to technology transfer. All these three variables are statistically significant. 
Table 3.Unit root test (ADF)

\begin{tabular}{|l|l|l|}
\hline Order of Integration & Variables & Test Statistics \\
\hline Level & LOFDI & -2.231639 \\
\hline First Difference & DLOFDI & $-5.643564^{* *}$ \\
\hline Level & LR & -0.017126 \\
\hline First Difference & DLR & $-2.680824^{* *}$ \\
\hline Level & LRT & -0.909287 \\
\hline First Difference & DLRT & $-3.997966^{* *}$ \\
\hline Level & LT & 2.407581 \\
\hline First Difference & DLT & $-1.815899^{*}$ \\
\hline Level & LTO & -0.240391 \\
\hline First Difference & DLTO & $-4.155774^{*}$ \\
\hline
\end{tabular}

**represents a stationary variable at $1 \%$ level of significance,

* represents a stationary variable at $5 \%$ level of significance

Table 4.Johansen and Juselius Co- integration Test TATA MOTORS

Trend Assumption: Linear Deterministic Trend

Unrestricted Co-integration Rank Test

\begin{tabular}{|c|c|c|c|c|c|}
\hline \multicolumn{2}{|c|}{ Hypothesis } & $\begin{array}{c}\text { Trace } \\
\text { Statistics }\end{array}$ & $\begin{array}{c}\mathbf{0 . 0 5 \%} \\
\text { critical value }\end{array}$ & $\begin{array}{c}\text { Max-Eigen } \\
\text { Statistics }\end{array}$ & $\mathbf{0 . 0 5 \% \text { critical value }}$ \\
\hline Null & Alternative & & & & \\
\hline $\mathrm{r}^{*}=0$ & $\mathrm{r}=1$ & 114.2684 & 47.85613 & 68.30776 & 27.58434 \\
\hline $\mathrm{r}^{*} \leq 1$ & $\mathrm{r}=2$ & 45.96062 & 29.79707 & 29.64391 & 21.13162 \\
\hline $\mathrm{r}^{*} \leq 2$ & $\mathrm{r}=3$ & 16.31671 & 15.49471 & 14.38826 & 14.26460 \\
\hline $\mathrm{r} \leq 3$ & $\mathrm{r}=4$ & 1.928451 & 3.841466 & 4.928451 & 4.841466 \\
\hline
\end{tabular}

* denotes rejection of the hypothesis at the 0.05 level

Table 5.Johansen and Juselius Co- integration Test RELIANCE

Trend Assumption: Linear Deterministic Trend

Unrestricted Co-integration Rank Test

\begin{tabular}{|c|c|c|c|c|c|}
\hline \multicolumn{2}{|c|}{ Hypothesis } & $\begin{array}{c}\text { Trace } \\
\text { Statistics }\end{array}$ & $\begin{array}{c}\mathbf{0 . 0 5 \%} \\
\text { critical value }\end{array}$ & $\begin{array}{c}\text { Max-Eigen } \\
\text { Statistics }\end{array}$ & $\mathbf{0 . 0 5 \% \text { critical value }}$ \\
\hline Null & Alternative & & & & \\
\hline$r^{*}=0$ & $\mathrm{r}=1$ & 129.5502 & 47.85613 & 99.92166 & 27.58434 \\
\hline $\mathrm{r}^{*} \leq 1$ & $\mathrm{r}=2$ & 29.62857 & 29.79707 & 21.10260 & 15.13162 \\
\hline $\mathrm{r} \leq 2$ & $\mathrm{r}=3$ & 14.52596 & 15.49471 & 9.919752 & 14.26460 \\
\hline $\mathrm{r} \leq 3$ & $\mathrm{r}=4$ & 3.606213 & 4.841466 & 2.606213 & 3.841466 \\
\hline
\end{tabular}

* denotes rejection of the hypothesis at the 0.05 level 
Table 6.FMOLS tata motors

Dependent Variable: LT

Method: Fully Modified Least Squares (FMOLS)

Sample (adjusted): 20042017

Included observations: 14 after adjustments

Cointegrating equation deterministics: $\mathrm{C}$

Long-run covariance estimate (Bartlett kernel, Newey-West fixed bandwidth

$$
=3.0000 \text { ) }
$$

\begin{tabular}{crrrr}
\hline & Coefficie & & & \\
Vt & Std. Error & t-Statistic & Prob. \\
& & & & \\
\hline LR & 26.17567 & 4.358005 & 6.006341 & 0.0001 \\
LOFDI & 2.115426 & 0.504985 & 4.189085 & 0.0019 \\
LTO & 5.574063 & 1.939883 & 2.873402 & 0.0166 \\
& - & & & \\
C & 41.12791 & 6.175437 & -6.659919 & 0.0001 \\
& & & & \\
& & & & 8.43234 \\
& & & & 6 \\
R-squared & & & & \\
& & & & \\
Adjusted R-squared & 0.736479 & S.D. dependent var & 4 \\
& & & & 16.0878 \\
S.E. of regression & 1.268380 & Sum squared resid & 9 \\
Long-run variance & 0.952275 & &
\end{tabular}




\section{Table 7.fmols reliance}

Dependent Variable: LRT

Method: Fully Modified Least Squares (FMOLS)

Sample (adjusted): 20042017

Included observations: 14 after adjustments

Cointegrating equation deterministics: $\mathrm{C}$

Long-run covariance estimate (Bartlett kernel, Newey-West fixed bandwidth

$=3.0000)$

\begin{tabular}{|c|c|c|c|c|}
\hline Variable & $\begin{array}{r}\text { Coefficie } \\
n t\end{array}$ & Std. Error & t-Statistic & Prob. \\
\hline LR & 19.34264 & 2.688034 & 7.195831 & 0.0000 \\
\hline LOFDI & 0.821184 & 0.311477 & 2.636420 & 0.0249 \\
\hline LTO & 4.910031 & 1.196527 & 4.103568 & 0.0021 \\
\hline $\mathrm{C}$ & 22.06327 & 3.809033 & -5.792355 & 0.0002 \\
\hline & & \multirow{2}{*}{\multicolumn{2}{|c|}{ Mean dependent var }} & 9.56245 \\
\hline R-squared & 0.871759 & & & 2 \\
\hline Adjusted R-squared & 0.833287 & \multicolumn{2}{|c|}{ S.D. dependent var } & 9 \\
\hline S.E. of regression & 0.662046 & \multirow{2}{*}{\multicolumn{2}{|c|}{ Sum squared resid }} & 0 \\
\hline Long-run variance & 0.362290 & & & \\
\hline
\end{tabular}

\section{Section V-Conclusion}

The economic reforms implemented in India has resulted in the transformation of economy to a fastly growing one. Both the trade and foreign direct investment sectors have performed well. In due course of time many Indian industries have grown to multinational companies. This had many implications such as capital flow, technology transfer etc. The detailed analysis of two leading multinationals such as Tata Motors and Reliance Industries has revealed that the prospects of technology transfer are enormous.

The analysis of determinants show that the variables such as research and development expenditure by government, trade openness and outward foreign direct investment have resulted in significant technology transfer by multinationals of Indian origin. From this analysis, we may draw the inference that the rigorous open economic policies are to be continued for the attainment of better economic prospects of the country.

\section{References}

Aggarval, Raj and James K.Weekly(1982), Foreign operations of Third World Multinationals: A Literature Review and Analysis of Indian companies, The Journal of Developing Areas, Vol.17, No.1, October, PP 13-30.

Ayres, Clarence E.(1953), The Role of Technology in Economic Theory, The American Economic Review, Vol.43, No.2, May, PP 279-289.

Fazal, Syed Ali and Abdul Wahab(2014), A Review on Technology transfer in context of Multinational corporations , International Journal of Business and Technopreneourship, Vol.4, No 3, October, PP 439-449.

Iyer, G. Chidambaran(2009), Indian multinationals, foreign multinationals and domestic firms, Journal of Economic Policy Reform, Vol.12, No.3, September, PP243-247

Kumar,Nagesh (1995), Changing Character of Foreign Direct Investment from Developing Countries case studies from Asia, UNU-INTECH Discussion paper No.9516.

Metcalfe, J.Stan(2010), Technology and Economic Theory, Cambridge Journal of Economics, Vol.34, PP. 153-171. 
Oliveira, Teresa de and Franz Paul Mayer (2017), Technology transfer between EU and India, Challenges and Opportunities INDIGO policy project, April, Vienna.

Radosevic, Slavo(1999), International technology transfer and catch-up in Economic development, Edward Elgar, Cheltenham, PP.14-30.

Tiwari, Rajnish and Cornelius Herstatt(2009), The Emergence of Indian Multinationals: A study of Indian Investments in Germany, Hamburg University of Technology, Working Paper No.56.

WahadSazali Abdul at.al(2012), Exploring the Technology Transfer Mechanisms by the Multinational Corporations: A Literature Review, Asian Social Science, Vol.8, No.3, March, PP 142-150.

Yang, Shenglang at al (2018), Determinants of Intangible and its impacts on Firms' productivity: Evience from Chinese Private Manufacturing Firms, China and World economy, Vol.26, No.6, PP 1-26. 